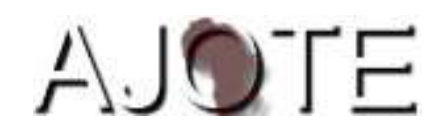

African Journal of Teacher Education

ISSN 1916-7822. A Journal of Spread Corporation

Volume 82019 Pages 299-320

\title{
East African Higher Education and the limitations of institutional reforms: A case study of selected public universities.
}

\author{
Philipo Lonati Sanga \\ School of Education, University of Dar es Salaam \\ Email: philipolonati@gmail.com
}

\begin{abstract}
Globally, universities are engaged in various aspects of reforms to improve their outlook and relevance. In East Africa, despite the similarities in many dimensions of socio-economic conditions, universities vary in terms of focus and extent of engagement in educational reforms. In order to examine this phenomenon more closely, three purposely-selected East African public universities were studied. Analysis of related documents as complemented by responses from key officials of these institutions revealed several findings: the University of Dar es Salaam's reforms seemed to conform more to characteristics of competitiveness-driven reforms, the University of Nairobi exhibits equitydriven reform, and Makerere University practises finance-driven reforms. Furthermore, the findings register limitations of effective institutional reforms such as massification of higher education, infringement of university autonomy, emerging technologies, paradox of internationalization, and the incapacity to cater to holistic students' welfare. The study concluded that, despite the myriad of limitations that the universities face, they have numerous opportunities which if efficiently utilized will enable them run the higher education race more triumphantly. The paper recommends that strategies for reforms should not derail the universities from their mandate to serve their respective countries.
\end{abstract}

Keywords: Challenges of reforms, East African higher education, institutional reforms.

\section{Introduction}

Literature and anecdotal evidence support that globalisation has affected many aspects of our life, one of those being education (Commonwealth of Learning [COL] (2019). For instance, Aarts and Greijn (2010), Kinyanjui (2007) and Goujon, Haller and Kmet (2017) highlight that globalisation is changing the ways that knowledge and skills are produced, disseminated and utilized. Agreement on what the term globalisation actually refers to or when in fact the 
world entered a global age has been difficult (Collins \& Rhoads, 2008). Moreover, knowledge is increasingly becoming a commodity that moves between countries. The rapidly increasing demand for higher education, in turn, surpasses the capacity of many countries to provide it locally. Likewise, universities in East Africa have been directly influenced by the irresistible wave of globalisation. Since the last decade, East Africa has witnessed reforms taking place in curriculum and general ways of doing things in many of its universities for the sake of improving their outlook.

Although institutional reforms may be taking place at a remarkable magnitude in Africa generally, little has been published on the extent to which African universities are globally competitive. Teferra \& Greijn (2010) argue that, although the systems of higher education in Africa are the most marginalised in the world, there is ample evidence that they may be among the most active in reform processes in terms of form, dimension, and scope. Obscurity of its actual situation is partly attributed to historical, socio-political, economic, and paradigmatic factors. Thus, as Marshall (2013) observes, besides wanting to widen their cultural and intellectual horizon or find knowledge and skills to give them a competitive advantage in the job market, African students typically leave their countries because the universities there have insufficient resources or do not offer the required education. This raises the question of what 'required' education in the African context entails. Can a country provide education that is contextually 'required' in another country?

Most of the initiatives and reforms being made by institutions of higher education in East Africa and Africa at large apply the DNA theory of fostering local knowledge. Cheng (2003, p.12) explains that this theory underlines the need to identify and transplant "the better key elements from the global knowledge to replace the existing weaker local components in the local developments." It means that fostering local knowledge is mainly a process to replace the invalid local knowledge with the relevant global knowledge through globalised education. This idea seems to concur with Nyerere's ideas, that:

It is necessary that we should be clear in our own mind about the function of university in the modern world....Only when we have done this can we avoid the twin dangers, on the one hand, of considering our university in the light of some mythical 'international standards', or, on the other hand of forcing our university to look inwards and isolate itself from the world in which we live 
(Nyerere, 1970).

Various literature indicates that Tanzania, Uganda and Kenya are regularly among the top twelve African countries sending students abroad for university education (Kishun, 2006; Goujon, Haller \& Kmet, 2017). Other countries of origin of the greatest numbers of Africans studying abroad are Morocco, Nigeria, Algeria, Zimbabwe, Cameroon, Tunisia, Senegal, Egypt and Botswana. On the other hand, the top ten destinations of African students for university studies abroad are usually France, USA, South Africa, United Kingdom, Germany, Portugal, Australia, Morocco, Canada and India. The list for top African countries sending students abroad and that of top destinations of African students for university studies abroad tend to change with time. An interesting phenomenon, however, is that even African countries are found in the list of top destinations for university studies abroad: South Africa, Morocco and sometimes Angola. It is logical to argue by reference to these few African destinations that African countries can somehow reverse the interests of their students who desire to study abroad.

Universities are reforming and consolidating aspects like teaching, research and innovation, information and communication technology application, funding, and scholarship to ensure that they produce competitive graduates who are well equipped to tap global knowledge resources and apply their education to support local and regional development (Nyaigotti-Chacha, 2004; Sørensen, 2009; Teferra \& Greijn, 2010).

\section{The Purpose}

The purpose of this paper is to trace the implementation of institutional reforms in East African universities in the era of globalisation. Towards this end, the specific objectives are to:

1. trace the context of East African public universities reforms,

2. examine the priority activities undertaken for institutional reform, and

3. analyse the limitations that these universities face in their pursuit to reform in this era.

\section{Methodology}

This paper draws conclusions dominantly from analysis of documents belonging to the three oldest public universities in East Africa: The University of Dar es Salaam (Tanzania), Makerere University (Uganda) and the University of Nairobi (Kenya). These three are not 
necessarily representative of all public universities in East Africa but they possess many common characteristics and a shared history which render them key icons of higher education in the region. Up until data collection for this study began, these three universities were the oldest, largest, and most reputable public universities in their respective countries. Information about the background and priority activities of the institutions was chiefly obtained from the documentary analysis of the institutions' comprehensive strategic plans. Institutions' websites supplemented the data needed for this study.

Further, a detailed structured questionnaire was administered to three staff in charge of institutional policy and planning for each of the three institutions. Information obtained from these nine questionnaires served the purpose of giving data for the three objectives of this study, especially the third one. Equally important, questionnaire responses helped to validate certain documentary information. Data obtained from all sources were sorted into four themes: context of institutional reforms, priority activities for institutional reforms, limitations of institutional reforms and other the background of universities in east Africa which was deemed useful to set the tone of the findings

\section{Background of Universities in East Africa}

The history of higher education in East Africa can be traced back to 1922 when Uganda Technical School, later renamed Uganda Technical College, was established. In 1937, the college expanded into an institution of higher education before it became a University College of the University of London in 1949 (Makerere University, 2010). Afterwards, it became a college for the whole of East Africa, offering courses which led to awards and distinctions. Until the early 1950s, it was the only college providing university education in East Africa. In 1956 the Royal Technical College was established in Nairobi, Kenya. Then, in 1963, the Royal Technical College became the University College, Nairobi following the establishment of the University of East Africa with three constituent colleges in Nairobi, Dar es Salaam, and Kampala (Nyaigotti-Chacha, 2004). In Tanzania, up until the time of independence from British colonialism in 1961, there were no universities available locally. Africanising the workforce became the main challenge of nationalistic leadership, hence the establishment of the University College Dar es Salaam as a college of the University of London with fourteen students. It became a constituent college of the University of East Africa in 1963 (University of Dar es Salaam [UDSM], 2011). The University of East Africa 

public universities.

offered programmes and degrees from the University of London until 1966. The dissolution of the University of East Africa in 1970 led to the creation of the three first autonomous public Universities of Dar es Salaam (UDSM), Makerere, and Nairobi in Tanzania, Uganda, and Kenya, respectively (UDSM, 2011).

East African countries are increasingly becoming cognisant of the principle that the capacity to assimilate knowledge, especially that knowledge attainable from higher education, is a key factor in any nation's struggle for socio-economic development. The manifest expansion of the higher education sector seems to be inexorable in all these countries. Figures 1-2 show the undergraduate (UG) and postgraduate/graduate (PG) students' enrolment for the academic years whose data are available for UDSM and Makerere university. Reliable data for the University of Nairobi was not available from the accessible documents.

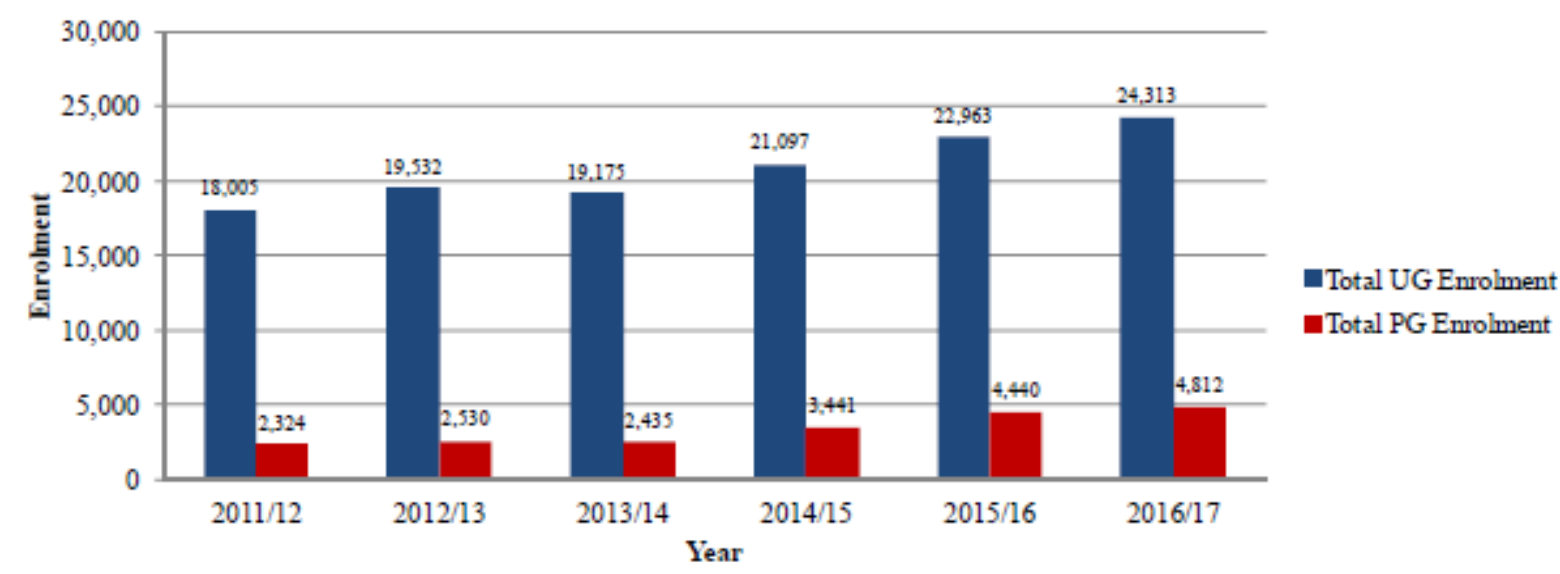

Figure 1: UDSM Undergraduate and Postgraduate Enrolment Trend 2011/12-2016/17

Source: UDSM facts and figures 2016/17 


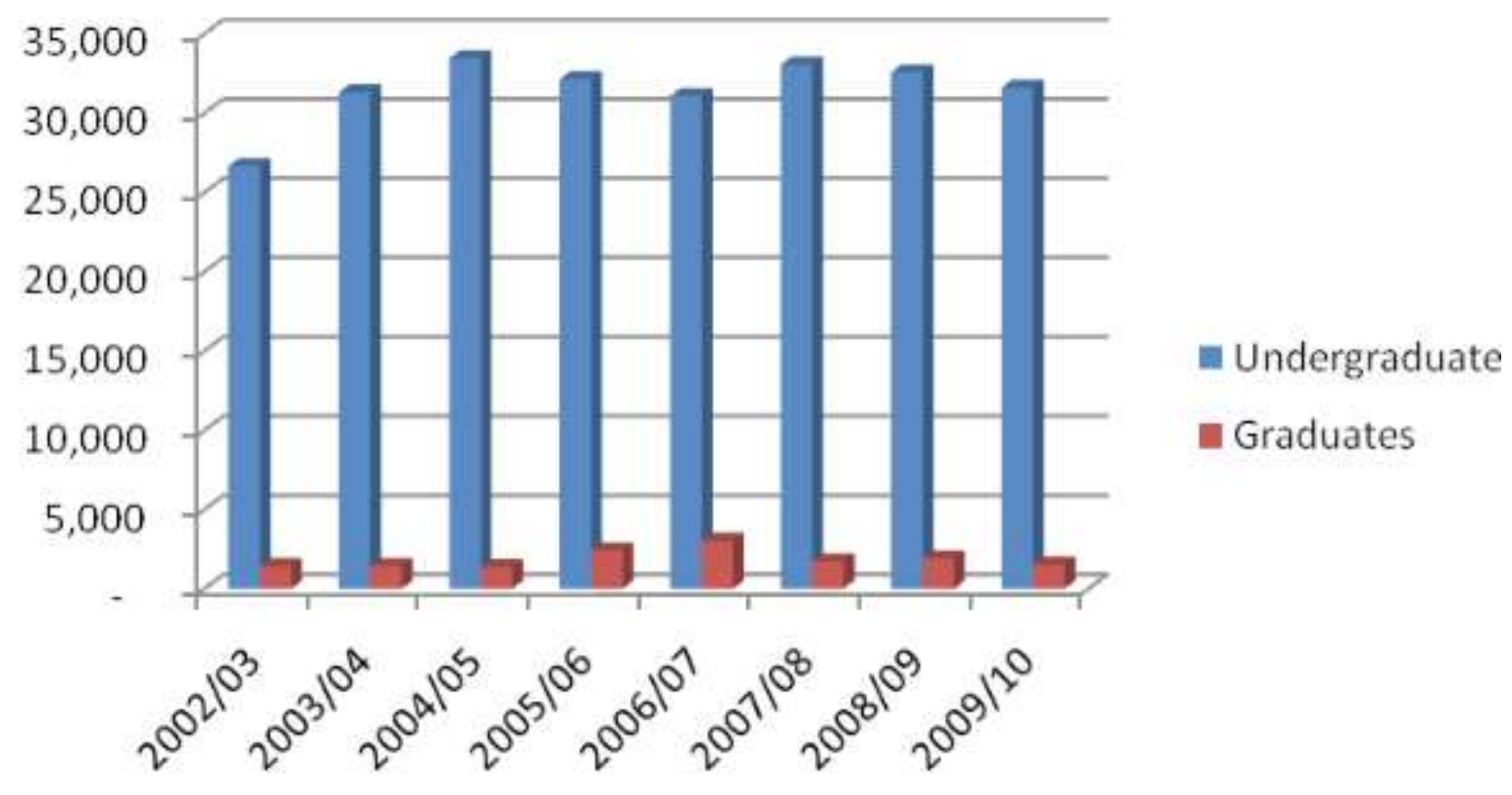

Figure 2: Makerere University Undergraduate and Postgraduate Enrolment Trend 2002/032009/10

\section{The Context of University Reforms in East Africa}

Chinnamai (2005) and COL (2019) posit that the globalisation of higher education is linked to both internal and external forces. Chan (2004) and Haigh (2008) outline economic, academic, and socio-cultural drives to this phenomenon. While it is apparent there are diverse forces behind the globalisation of higher education, De Wit (2002) perceives that different institutions, stakeholders, and groups of individuals do not have a single exclusive reason for that trend.

Major reforms at the University of Dar es Salaam (UDSM) came at the same time as reforms in Tanzania's banking and financial sectors which had been mandated by the International Monetary Fund (IMF) (Nyerere, 1995). Luhanga, cited in Bollag (2004), reveals that some people wrongly perceived that UDSM's reforms had also been mandated by the IMF. The 1980s global economic crisis left the University of Dar es Salaam with diminished government funding. Factors, which included low salaries of academics in the Engineering discipline compared to their counterparts employed in other sectors saw this faculty losing the most academic staff. Responding to this challenge, the Faculty of Engineering pioneered a series of reforms whose first step was to establish a Bureau for Industrial Cooperation 
(BICO) to promote consulting work and allow faculty members and their departments to earn extra income.

It was later thought necessary to replicate this model within the entire university. The first draft of this institutional strategic plan was presented in 1992 to a meeting of the university community and foreign donor organisations. This yielded a final publication of the Corporate Strategic Plan (CSP) in 1994 which has been the basic guide for the university's transformation. The plan plainly states that the university's mission must adapt to meet the profound changes taking place within the country. However, faced with a collapsing economy and pressure from global lending organisations, the government opened up the economy to private ownership and foreign investment. Therefore, the changing labour market required the university curricula to produce graduates with skills different from those traditionally offered. In response to the observed constraints and considering the current and new national and global developments, the university reviewed the CSP in 2003 to cover the period between 2004-2014. The main focus areas of CSP 2004-2014 are to ensure capacity development, quality assurance, and outreach activities by closely reflecting upon the university's vision, mission, and its core functions (UDSM, 2011). The genesis of UDSM's reforms can be considered to be an example of a top-down revolution (Luhanga, 2003).

The reforms of the University of Nairobi were very much influenced by the Public University Inspection Board's report which prompted all universities in Kenya to undergo a transformation to be compatible with the developmental and entrepreneurial qualities of the $21^{\text {st }}$ century and address many issues including the increasing demand for access and equity. The paradigm shift involved a transformation of higher education for combating national problems and tackling global challenges. It is with this understanding that the University of Nairobi had to review the strategic plan of 2005-2010 and recast it to 2013 (University of Nairobi Strategic Plan, 2008-2013). The university was therefore obliged to plan a new strategic direction while at the same time being increasingly aware of the importance of its position in a global community.

The institutional transformation of Makerere University is referred to as "a quiet revolution" by some authors (Makerere University, 2000, p. ii). Makerere University's institutional reform was essentially an implementation of alterative financial strategies as a response to the government's reduced commitment in financing higher education (Kwesiga \& Ahikire, 2006). The university had to envision being market-oriented and one means to this 
path was the introduction of the private sponsorship programme in 1992 which significantly stretched the intake of fee-paying students. About seven years later, Makerere had leaped from its none fees paying position to one where $80 \%$ of students paid fees, accounting for more than $50 \%$ of the university's total revenue. Emphasis on a private sponsorship programme notwithstanding, enrolment at Makerere University has been burgeoning yearly. Currently, the university is profoundly dominated by privately sponsored students. Due to a public outcry that massive enrolment numbers are harmful to the quality of education, the Uganda National Council for Higher Education (NCHE) resorted to implementing student admissions ceilings for all programmes and to all universities within the country (Makerere University, 2010).

Analysis of these institutions' background for educational reforms suggests that their decisions to undertake institutional reforms were driven by different motives. Carnoy (1999) proposes three categories of reforms. The University of Dar es Salaam's reforms conform more to characteristics of competitiveness-driven reforms. These reforms focus on improving productivity, the quality of the "human factor" (Organisation for Economic Co-operation and Development, in Carnoy, 1999, p. 37), and of the institution. Strategies to achieve competitiveness include decentralisation, quality assurance, improved management of institutional resources, and development of academic staff recruitment and training. The University of Nairobi experienced equity-driven reforms whose philosophy is to increase equality through increasing accessibility to education. Ostensibly, Makerere University's interpretation of globalisation is increasing competition among institutions and nations in a more knotted, international economy, hence finance-driven reforms.

\section{Priority Activities for Institutional Reforms}

The strategic choices to address the implications of globalisation appear to differ somehow in terms of scale of preference among these East African universities. Hereunder is the summary for the main priority activities which are strategically implemented by each university. 
East African Higher Education and the limitations of institutional reforms: A case study of selected public universities.

Table 1.

Top Priority Activities for Reforms

\begin{tabular}{|c|c|c|}
\hline University of Dar es Salaam & University of Nairobi & Ma \\
\hline $\begin{array}{l}\text { - Curricular reforms to encourage } \\
\text { entrepreneurship skills. Thus, putting } \\
\text { more emphasis on teaching students } \\
\text { business and financial skills, } \\
\text { - Optimising the use of all the } \\
\text { institution's resources through further } \\
\text { expansion of student enrolment to } \\
\text { optimise the formerly overstaffed } \\
\text { university and widening access to } \\
\text { university education, } \\
\text { - Upgrading Advanced Information and } \\
\text { Communication Technology (ICT) } \\
\text { infrastructure and enhancing } \\
\text { information systems, } \\
\text { - Increasing academic support through } \\
\text { converting traditional teaching/ } \\
\text { learning materials into electronic } \\
\text { format, enhancing instructional } \\
\text { technology resources (software \& } \\
\text { hardware), and promoting e-Learning } \\
\text { initiatives, and } \\
\text { - General staff development to improve } \\
\text { the quality of education. } \\
\text { (Source: University of } \\
\text { Dar es Salaam Revised Corporate } \\
\text { Strategic Plan, 2004-2014) }\end{array}$ & $\begin{array}{l}\text { - Promoting innovative, } \\
\text { diversified modes of delivery } \\
\text { (technology \& distance } \\
\text { education), } \\
\text { - Creating and enabling } \\
\text { environment and policy } \\
\text { framework that promotes } \\
\text { research, development, and } \\
\text { other value adding services, } \\
\text { - Developing effective leadership } \\
\text { systems: visionary, innovative } \\
\text { leadership \& management that } \\
\text { is visible, open and transparent, } \\
\text { and } \\
\text { attracts and maintains highly } \\
\text { qualified staff, } \\
\text { - Strengthening the existing } \\
\text { partnerships and linkages and } \\
\text { developing new ones, locally } \\
\text { and internationally, and } \\
\text { - Increasing internally generated } \\
\text { revenue, instilling fiscal } \\
\text { discipline in all operations, and } \\
\text { maintaining a balanced budget. } \\
\text { (Source: University of Nairobi } \\
\text { Strategic Plan 2008-2013) }\end{array}$ & $\begin{array}{l}\text { - Diversifying income } \\
\text { generation sources, } \\
\text { - Investing in E-Learning } \\
\text { systems, } \\
\text { - Engaging in International } \\
\text { partnerships and distance } \\
\text { education, } \\
\text { - Boosting quality assurance } \\
\text { in order to become } \\
\text { internationally competitive } \\
\text { and } \\
\text { - Expanding capacity in } \\
\text { medical, technology, and } \\
\text { science education. } \\
\text { (Source: Makerere } \\
\text { University Strategic Plan } \\
\text { 2008/09 - 2018/2019) }\end{array}$ \\
\hline
\end{tabular}

The activities and strategies adopted by these universities seem to directly reflect the aspects of reforms which are principally emphasized by each university. For example, it has been realized that the University of Dar es Salaam's competitiveness-driven reforms focus most on transforming the curriculum, above all, to prepare students with entrepreneurial knowledge and skills and on upgrading ICT infrastructure. In this way, students are prepared to be globally competitive not only academically but also socially and technologically. The 
University of Nairobi's equity-driven reforms focus chiefly on implementing innovative academic curriculum but with a special emphasis on fostering a flourishing environment for research. Makerere University's concentration is on income generation and expanding horizons for international partnership. Finance-driven reforms have made it possible for Makerere University to be an exemplary model in attracting privately-sponsored students, through which about 50 per cent of the university's revenue is generated. Differences in priority strategies for globalisation may not necessarily be a fundamental reason for variation in the speed and nature of reforms among these institutions, but rather, may be a result of the firmness and consistency the institution employs to implement its priority strategies.

\section{Some Limiting Factors}

There are many limitations that universities in East Africa face as they struggle in implementing reforms within the era of globalisation. These limitations mitigate the institutions' commitment to maximising their potential in realising their missions and goals. While these universities certainly face many challenges, this study unveiled the following to be the primary hurdles.

\section{Massification of higher education}

In regard to East African universities, UNESCO's basic Education for All movement (Jomtien, 1990) appears to have induced a higher education for all fallacy. In this paper, massification refers to the increase in student enrolment in higher education institutions. This phenomenon directly induces a sharp increase in the number of institutions, as well as fundamentally different types of institutions, as the diverse needs of students become "reflected in the programmatic and institutional structures of the system" (Gumport, 1997, p.2). Most of these universities, especially private ones in Tanzania, Kenya, and Uganda, have mushroomed within the last decade. While the use of national enrolment ratios or participation rates may be appropriate to define massification of higher education in heavily industrialised countries, this may not necessarily be the case for less industrialised countries, like those sampled in this study. These countries have a very low higher education enrolment to population ratio but they have experienced a very rapid increase in actual numbers of students enrolled in higher education within the last decade. 
Accommodating large numbers of students wishing to access higher education in East African countries became an imperative, the reason these three universities are critically overcrowded just like other public universities in the region. Poor planning coupled with a meagre supply of resources tend to exacerbate the problem of overcrowding. In Kenya, the admissions crisis had existed for decades and caused a backlog that had forced students accepted to the university to wait for two years before they could be admitted for studies. Recently, the government of Kenya called for an end to the long wait through a double intake plan, such as through admitting over 8,000 more students in 2011 than in the previous year (Ndanyi, 2011).

Undesirable effects of massification notwithstanding, there are desirable effects too. For instance, by and large, massification is a good vehicle for widening access to higher education because one of the greatest needs of these countries is highly skilled and resourceful human capital to push forward the national development agendas. The belief is that quantity yields quality in the long run.

Furthermore, establishing and nurturing a truly competitive university calls for a direct involvement of national governments through practical policy intervention and financing. Although there are certainly many paths towards this goal, a choice may be required to be made from at least three pre-conditions as put otherwise by Liu, Wang and Cheng (2011). Firstly, consider upgrading a small number of existing universities that have the potential for outshining others. Secondly, encourage a number of existing institutions to synergise. Thirdly, create new competitive universities from scratch. Each option has strengths and weaknesses which must be weighed accordingly before decisions to opt for it are made.

\section{Infringement of university autonomy}

This study revealed that these three universities share a common cry for autonomy and academic freedom. Omari (1991) describes university autonomy as the extent of the proximity of the state to the university. University autonomy can be referred to as the freedom given to universities and manifested in processes such as governing themselves, appointing key staffs, determining the conditions of service of their staff, controlling their students, admissions, and academic curricula, controlling their finances and generally regulating themselves as independent legal entities without unnecessary interference from the government and its organisations. Further, Mazrui, cited in Omari (1991), decries the AJOTE Vol. 9 (2019), 299-320 
proximity between the universities and the national structure of power which in Africa has tended to curtail academic freedom and consequently intellectual expansion among students and staff. For example, there have been reported cases of either direct or indirect government encroachment on university recruitment and contract renewal of retiring dons (University of Dar es Salaam); university budget and spending (Makerere University); and curriculum and timetables (University of Nairobi) as it can be reflected from the excerpt below:

From now on, the University of Nairobi will be answerable to the government and to the ruling party. ... I do not want to hear any more demands for such a thing as academic freedom. Who will give you academic freedom? Who pays your salary? Even at Cambridge, there is no such thing as academic freedom. Because the government pays it, they do what the government wants. What are you going to do with this academic freedom that you people of the University of Nairobi are calling for? (Former President of Kenya, Moi, cited in Chege, 2006).

In the view of this paper, education, and especially higher education is a political enterprise. It is neither feasible nor justifiable that any sensible government does not take part in its universities' affairs. Accordingly, government intervention is absolutely justifiable but should be skilfully undertaken. Rather than the involvement of the government per se, what requires cautiousness is the extent and manner of the interferences. Also, while university autonomy is a necessity for achieving excellence, it is not a sufficient condition. Limitation to autonomy in terms of accountability to the state and other stakeholders is indispensable to ensure these universities' good governance.

It is compelling to realise, however, that the debate around accountability of African states and their higher education systems is much linked to the debate around financial resources and how the resources are allocated since the national governments provide the major funding for public universities (Maduekwe, 2015). Accountability may therefore be viewed as a governance principle to steer universities to be responsive to governmental mandates and policies in the African context. This is evident in the Tanzanian situation where public universities are expected to be responsive to the higher education reform initiatives 
that emanate from the state (see for example, the access, quality, funding, and community service as stipulated by the MKUKUTA policy document)

The challenge regarding autonomy for the university has always been in terms of how to position itself amongst the three strong categories of forces: professional/ academic oligarchy, government/state authority, and market forces as portrayed by Clark's triangle (See Figure 3). Again, Tudiver (1999) warns:

Universities driven by market priorities provide a limited contribution to democratic processes. They cannot foster the kind of debate and social criticism that thrives in an independent academy (Readings, 1996). The university is supposed to be a forum for open debate from all perspectives ( $p$. 189).

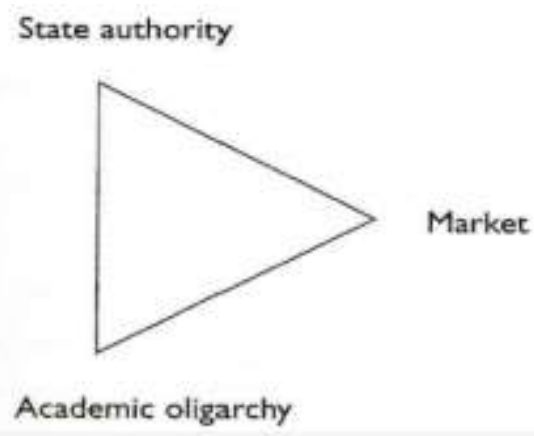

Figure 3: Clark's triangle for forces affecting university autonomy

\section{Limitations related to emerging technologies}

Advanced Information and Communication Technologies (ICTs) hardware and software are yet to be effectively exploited by these universities. For instance, computing facilities (computers, printers, photocopiers and scanners) in students' public access rooms and places are inadequate. Although these institutions are better internet-connected compared to most public and private universities in their respective countries, their reliability is low and access to them daunting. In most cases, the campus buildings have a low capacity for these technologies, they equipped with an obsolete backbone network infrastructure and poor or unstructured Local Area Network (LAN). Similarly, Wireless Local Area Networks 
(WLAN), which is one among the many appropriate options for generating better technologies at these institutions, is seldom put to use. The National Networked Readiness Indexes (NRI) equally influence these institutions' extent of access to ICTs. Literature indicates that Kenya is ahead of Tanzania and Uganda in terms of access to ICTs (Bon, 2010).

Advanced ICTs are imperative for universities to discharge their functions more competitively in this digital era. Although one could expect all university classrooms and learning venues to be at least internet connected, the situation is such that very few classrooms are outfitted with such technologies; even in these most prestigious universities in the region. As such, common synchronous technologies like videoconferencing and web conferencing on one hand, and asynchronous technologies like discussion forums, Google, and wiki searching on the other hand, are rarely promoted within the classroom setting. In spite of the clear opportunities related to ICTs that these universities have, there is still a lack of real awareness about the benefits of ICTs as a result of biased mindsets, an unwillingness to face the technological changes occurring in universities, and a lack of a clear perception as to how ICT resources can be sustainably managed.

\section{The paradox of internationalisation}

While all these East African universities would confidently declare to be effectively implementing internationalisation strategies, this study revealed that in most cases there is actually more localisation and slightly regionalisation than authentic internationalisation. For instance, regarding enrolment of international students, Makerere University Fact Book (2011) documented that Makerere University admitted 1,135 foreign students in 2010/11 (3.4\% of total enrolment) out of which 1,023 (90\%) came from Kenya and 88 students (7.8\%) from Tanzania. Only 3 students enrolled at Makerere in 2010/2011 were non-African nationalities. The average percentage of international students being admitted at the University of Dar es Salaam for the period 2005-2010 was 3.5\%, of which, similarly, was comprised mostly of students who hailed from East African countries. It can be argued that these 'international' students are not international in a strict sense, but rather 'local' and/or 'regional' students. 
Literature, however, suggests that this may be the trend of many institutions worldwide. For example, reviews of studies for two Asian national (public) universities which are regularly within the top 50 world universities corroborate this finding. Out of 28,017 students enrolled at the University of Tokyo in Japan in 2011 2,540 (9.1\%) were international students (The University of Tokyo, 2011). Among these international students, 1,678 $(66.1 \%)$ were from nearby China and Korea. Analysed otherwise, 2,443 international students $(96.2 \%)$ out of the total 2,540 international students at Tokyo University came from other Asian countries. Similarly, out the total enrolment of 28,018 students in 2011 at SNU, a mere 2,486 students (8.9\%) were international students (Seoul National University, 2011).

It is thus most likely that in many universities globally, 'international' students are actually 'regional' students from the closest neighbouring countries regardless of the way the institution may try to express its outlook. There is a potential for synergy between internationalisation and regionalisation of higher education but one can just as well limit the success of the other depending on their focus. In these universities, internationalisation has mainly involved new forms of providing higher education to students - sometimes without the relevant curriculum to suit local needs. Concurrently, regional approaches in the context of broader Pan-Africanism on the implications of internationalisation on the continent are being implemented. As such, internationalisation in these universities poses numerous questions in relation to the extent and intensity of their capability to address local and regional access, equity, research, and development agendas.

There is, yet one issue seemingly unresolved; institutions, including universities are usually encouraged to both cooperate and compete with one another. Nevertheless, in commercial spheres, there is a paradox of cooperation and competition. How can the two exist concurrently? Unless the institutional leadership is flexible and prudent enough, balancing cooperation and competition becomes a truly tricky undertaking.

\section{Incapacity to cater for holistic students' welfare}

Governments' reduced capacity for funding of higher education programmes has rendered universities paralytic in providing some necessary requirements for students' conducive life at universities. As such universities are sometimes confronted with recurring students' uproars and strikes. In 2011 alone both Makerere and Dar es Salaam universities experienced their students going on strike at various times. Recently, Nairobi University was involved in 
their academic staffs' strike in 2011 and 2018 and their student strike in 2010. The persistent student strikes are, by and large, one key symbol of student welfare anomalies. Every time students go on strike, they express to the respective authorities their desire for ultimate solutions. Normally, going on strike is said to be the last resort after having used all other traditional bureaucracies to express their demands. Despite the costs in terms of time, destruction and loss of property, injuries and even deaths of innocent individuals, ample evidence confirms that these strikes have ended with authorities' positive responses to the students' demands.

Student strikes are repeatedly associated with rising tuition fees, lack or poor practical training, biased Students' Loans Board procedures, poor housing and sanitation facilities and dissatisfaction with general learning conditions on campus. Although student welfare is a critical component of any university planning, it is often overlooked in some university planning agendas. Some educators and administrators tend to deliberately bypass issues directly related to student welfare. For instance, recommendations such as: "the admission of students to state universities should be de-linked from bed spaces but be linked to availability of academic and tuition facilities, ” as summarized by Kinyanjui (2007), must be criticised right away. Accommodation problems are among the key sources of student frustrations, thus, leaving the task of hunting for accommodation for students themselves is in no way justifiable. This is seriously risky, particularly when one considers the complexities and exorbitant cost of accommodations near these typically urban universities. Most importantly, the majority of private housing facilities and transportation to and from the campus are of very poor quality and are unsafe. To promote universities which can effectively compete in this era of globalisation, institutional and national policy makers have to consider students as major partners and responsible stakeholders in the process of policy making.

\section{Some opportunities available for East African universities}

Despite the myriad of limitations that these universities face, they have abundant opportunities which if efficiently utilized would enable them to achieve better results. The opportunities are such as: 
i. Growing recognition of the role of higher education in the national development. National governments in East Africa are rapidly acknowledging the critical contribution of higher education to socio-economic development plans.

ii. Institutional internationalisation strategies. The increasing admission of foreign students, academic staff collaboration in research and numerous international conferences foster cross-fertilisation of ideas.

iii. Strategies and innovative use of ICT and access to fast broadband internet. Innovative use of ICTs boosts international research activities and improves the local publishing infrastructure.

iv. Stable collaboration with global development partners. These universities enjoy longterm stable partnership and strategic development assistance from many reliable global partners such as the Africa Institute for Capacity Development (AICAD), Lake Victoria Basin Research Initiative, the Norwegian Agency for Development Cooperation (NORAD), Swedish Sida/SAREC, and the Carnegie Corporation.

\section{Conclusions and Implications}

It has been disclosed that institutional reforms in these three universities are motivated by both internal and external thrusts. Equally important, globalisation should not be perceived as a new phenomenon, but rather, 'old wine in a new wineskin.' Universities, by their very nature and functions ought to be global institutions from the moment of their establishment. Thus, an effective university should be relevant to both local and global contexts.

Hence, East African universities, both private and public, should always focus on their core functions in the changing world and be able to lead change but not by necessarily deviating from their core missions and visions. It is thus imperative to avoid the twin dangers, first, of considering themselves in the light of some mythical 'international standards' and second, of forcing themselves to look inwards and choose isolation from the world. Institutions of higher education in East Africa should proceed by applying the DNA theory of fostering local knowledge to prepare graduates with locally and globally mixed education, graduates who can act and think with both local and global awareness.

The widespread trend of excessive student enrolment seems to be inevitable in the present world. Despite the numerous political, social, and educational benefits of massification, counter-productive effects in terms of lowered quality of education, 
inadequacy of infrastructure and access to technology are evident. The alleged depreciation of higher education due to the provision of a plethora of quasi-academic courses that are irrelevant to both local and global labour markets should be appropriately dealt with by the nations' relevant higher education authorities.

Reform of university activities needs to be given a broader dimension to distinguish these universities from the current trend of localisation and regionalisation. For instance, filling in admission vacancies for foreign students with almost all the students coming from the neighbouring countries may fail to foster the desired impact on cross-cultural and intellectual fertilisation, an essential requirement for global competition. The study has established that more opportunity is available for universities to promote more harnessing of ICT for education purposes and applying the same for blended learning mode of delivery. This is in tandem to what Nyerere $(1995$, p.201) underscores that "Education and training, especially Science and Technology, are the keys to survival as well as to development in the future." Open and distance learning are two ways that ICT can offer cost-effective sharing of resources, support quality access to marginalized communities and equalise opportunities to learn and enhance affordability.

\section{References}

Aarts, H. and Greijn, H. (2010). Globalisation, knowledge and learning: Developing the capacities of higher education institutes. In D. Teferra \& H. Greijn (Eds.), Higher education and globalisation, challenges, threats and opportunities for Africa (pp. 6377). Maastricht: MUNDO.

Bollag, B. (Ed.) (2004). Improving Tertiary Education in Sub-Saharan Africa: Things that Work. Report of a regional training conference, Africa Region Human Development Working Paper Series.

Bon, A. (2010). Information and communication technologies in tertiary education in SubSaharan Africa. In D. Teferra \& H. Greijn (Eds.), Higher education and globalisation, challenges, threats and opportunities for Africa (pp. 63-77). Maastricht: MUNDO.

Carnoy, M. (1999). Globalisation and educational reform: what planners need to know.

Paris: UNESCO. 
Chan, W.Y. (2004). International cooperation in higher education: theory and practice. Journal of Studies in International Education, 8:32-55.

Chege, M. (2006). The state of higher education in Kenya: problems and prospects. Paper Presented at the Mijadala on Social Policy, Governance and Development in Kenya' sponsored by Development Policy Management Forum at Nairobi Safari Club, Nairobi, Kenya.

Cheng, Y. C. (2003). Local knowledge and human development in globalisation of education. International conference on globalisation and challenges for education. New Delhi: NIEPA.

Chinnamai, S. (2005). Effects of globalisation on education and culture. ICDE International Conference, New Delhi.

Collins, C.S. and Rhoads, R.A. (2008). The World Bank and higher education in the developing world: The cases of Uganda and Thailand. The Worldwide Transformation of Higher Education International Perspectives on Education and Society, 9, 177-221.

Commonwealth of Learning [COL] (2019). The road to 2030: Building a better world through higher education, strategy 2019-2025. The Association of Commonwealth Universities.

De Wit, H. (2002). Internationalization of higher education in the United States of America and Europe: A historical, comparative, and conceptual analysis. Westport, Connecticut: Greenwood Press.

Dibba-Wadda, O.L.C. (2019). Transforming higher education in Africa. In Commonwealth education report 2019, pp. 128-129. London: Commonwealth Business Communications Ltd.

Goujon, A., Haller, M. and Kmet, B.M. (2017). Higher education in Africa: Challenges for development, mobility and cooperation. Newcastle upon Tyne: Cambridge Scholars Publishing.

Gumport, P. J. (1997). Trends in United States higher education from massification to post massification. Stanford University: National Center for Post secondary Improvement. 
Haigh, M. (2008). Internationalization, planetary citizenship and higher education.

Compare, 38 (4), 427-440. http://www.eac.int/ retrieved on February 12, 2012.

Kenya National Bureau of Statistics (KNBS), retrieved from

https://www.knbs.or.ke/download/university-enrolment/

Kinyanjui, K. (2007). The transformation of higher education in Kenya: challenges and opportunities. Paper presented at the Mijadala on Social Policy, Governance and Development in Kenya sponsored by Development Policy Management Forum, Nairobi Safari Club, Nairobi, Kenya.

Kishun, R. (2006). Introduction: The internationalization of higher education in South Africa: Progress and challenges. In R. Kishun (Ed.), The internationalization of higher education in South Africa (pp. 1-12). Durban, South Africa: Astro Printers International Education Association of South Africa.

Kwesiga, J.C. \& Ahikire, J. (2006). On student access and equity in a reforming university: Makerere in the 1990s and beyond. JHEA/RESA, 4 (2), 1-46.

Liu, N. C., Wang, Q. and Cheng, Y. (Eds.). (2011). Paths to a world-class university, lessons from practices and experiences. Rotterdam. Sense Publishers.

Luhanga, M. (2003). Higher education reforms in Africa: the University of Dar es Salaam experience. Dar es Salaam: Dar es Salaam University Press.

Maduekwe, C. C. (2015). National higher education reform in Tanzania: Understanding institutional and state leaders' responses to access and quality initiatives at selected public universities. Unpublished PhD thesis, University of Western Cape: South Africa

Makerere University (2000). Strategic plan 2000/01-2004/05. Planning and Development Department: Kampala

Makerere University (2010). ICT Policy/Master Plan (2010 - 2014). Kampala: Makerere University. 
Makerere University Fact Book (2011). Retrieved March 22, 2012 from http://mak.ac.ug/about/facts-figures/enrolment.

Marshall, J. (2013, July 6). International mobility of African students - Report. University World News, Issue No:279

Ndanyi, M. (2011, June 22). UASU faults double-intake plan in universities. The Star. Retrieved March 22, 2012 from http://www.the-star.co.ke.

Nguyen, C.H. (2006). Brain drain or brain gain? The revitalization of slow death. Retrieved October 5, 2011 from http://www.usca.edu

Nyaigotti-Chacha, C. (2004). Reforming higher education in Kenya challenges, lessons and opportunities. Paper presented at the workshop for Parliamentary Committee on Education, Science and Technology, State University of New York, Naivasha, Kenya.

Nyerere, J.K. (1970, August). Relevance and Dar es Salaam University. Inaugural speech presented at the University of Dar es Salaam. Dar es Salaam, Tanzania.

Nyerere, J. K. (1995). Address at the twenty fifth anniversary of the university of Dar es Salaam. In E, Lema, I. Omari and R. Rajani, (Eds.) (2006). Nyerere on education volume II: Selected essays and speeches 1961-1997, pp. 192-203. Dar es Salaam: HakiElimu.

Omari, I. (1991). Higher education at crossroads in Africa. Nairobi: Man Graphics Limited.

Seoul National University (2011). Seoul National University. Retrieved February 2, 2012 from http://en.snu.ac.kr.

Sørensen, A. (2009). Internationalisation of higher education and research: The Case of SANORD, Final Report. Danish Development Research Network

Teferra, D. \& Greijn, H. (Eds.) (2010). Higher education and globalisation, challenges, threats and opportunities for Africa. Maastricht: MUNDO.

Tudiver, N. (1999). Universities for sale: resisting corporate control over Canadian higher education. Toronto: Canadian Association of University Teachers.

University of Dar es Salaam [UDSM] (2011). Facts and figures 2009/2010. Dar es Salaam: UDSM.

University of Dar es Salaam [UDSM](2011b). Revised corporate strategic plan, 2004-2013). 
Dar es Salaam: UDSM.

University of Dar es Salaam [UDSM](2017). Facts and figures 2011/12 - 2016/17. Dar es Salaam: Directorate of Planning and Development.

University of Nairobi (n.d). Strategic Plan 2008-2013. Nairobi: University of Nairobi.

University of Tokyo (2011). The University of Tokyo. Retrieved February 2, 2012 from http://www.u-tokyo.ac.jp 